\title{
LEAF HERBIVORY ON THREE TREE SPECIES IN A MONODOMINANT AND TWO OTHER TERRA FIRME FORESTS ON MARACÁ ISLAND, BRAZIL.
}

\author{
Marcelo T. NASCIMENTO ${ }^{1,2}$, John PROCTOR ${ }^{1}$
}

\begin{abstract}
The aim of this study was to test the hypothesis that the monodominant nonpioneer Peltogyne gracilipes, typically does not suffer density-dependent herbivory (JanzenConnell model). Two components of intraspecific variation in leaf herbivory were measured; 1) the variation between individuals in the population at the same time and 2) the temporal variation in rates of damage to each individual. The study was carried out on Maracá Island, Roraima, Brazil in three plots $(50 \mathrm{~m} \times 50 \mathrm{~m})$ in each of three forest types: Peltogyne-rich forest (PRF), Peltogyne-poor forest (PPF), and forest without Peltogyne (FWP). Two other non-pioneer species (Ecclinusa guianensis and Pradosia surinamensis) were chosen for comparison because they were fairly abundant and their seedlings could be readily identified. The values of leaf area removed by herbivores of trees and seedlings of the three study species were in the range reported for other tropical tree species (2-16\%, standing damage). There were no differences within species between forests. However, there was a significant difference among species but this was not correlated with seedling density. Peltogyne seedlings showed no evidence of density-dependent herbivory as predicted by the Janzen-Connell model despite the fact that adult trees were observed to suffer a mass defoliation in April 1992. This result suggests that Peltogyne may be dominant partly due to escape from herbivory in the early stages of its life although it may suffer occasional mass defoliation as an adult.
\end{abstract}

Key words: Amazonia, density-dependent herbivory, monodominant forest, Peltogyne, terra firme forest

Herbivoria Foliar em Três Espécies Arbóreas em Uma Floresta Monodominante e Duas Outras Floresta de Terra Firme na Ilha de Maracá, Brasil.

RESUMO - O objetivo deste trabalho foi testar a hipótese de que Peltogyne gracilipes, espécie climax e monodominante, tipicamente não sofre herbivoria dependente da densidade (Modelo de Janzen-Connell). Dois componentes da variação intraespecífica na herbivoria foliar foram avaliados: 1) a variação entre individuos na população no mesmo tempo e 2) a variação temporal na taxa de danos em cada indivíduo. O estudo foi realizado na Ilha de Maracá, Roraima, Brasil em três parcelas de $50 \mathrm{~m} \times 50 \mathrm{~m}$ em cada um dos três tipos florestais (Floresta rica em Peltogyne, PRF; Floresta pobre em Peltogyne, PPF e Floresta sem Peltogyne, FWP). Duas outras espécies não pioneiras (Ecclinusa guianensis e Pradosia surinamensis) foram escolhidas para comparações por serem abundantes nas diferentes classes de tamanho e suas plântulas de fácil identificação no campo. A percentagem de área foliar removida pelos herbívoros está entre os valores reportados para outras espécies arbóreas tropicais (2-16\%). Não houve diferenças dentro das espécies entre florestas. Entretanto, existiu uma diferença significativa entre espécies. As plântulas de Peltogyne não apresentaram nenhuma evidência de herbivoria dependente da densidade como previsto pelo modelo de Janzen-Connell, embora para árvores adultas tenha sido observado a ocorrência de desfolhamento em massa em abril de 1992. Este resultado sugere que Peltogyne pode ser dominante parcialemente devido ao escape da herbivoria nos estágios iniciais de sua vida embora possa sofre ocasionais desfolhamento quando adulta.

Palavras-chave: Amazônia, herbivoria dependente da densidade, floresta monodominante, Peltogyne, floresta de terra firme

'Department of Biological and Molecular Sciences, University of Stirling, Stirling, Scotland, FK9 4LA.

${ }^{2}$ Present address: Laboratório de Ciências Ambientais, Centro de Biociências e Biotecnologia, Universidade Estadual do Norte Fluminense, Campos dos Goytacazes, RJ, Brazil, 28015-620.mtn@uenf.br 


\section{INTRODUCTION}

The extent of herbivore damage may be affected by factors such as leaf age, leaf quality, plant size (Coley, 1983a; Marquis, 1987; Ernest, 1989; Aide, 1992; Kursar \& Coley, 1992; Nascimento 1989; Nascimento \& Hay, 1993; Coley \& Barone, 1996) and by the composition, density and diversity of the surrounding vegetation (Brown \& Ewel, 1987). The number of insects per plant and per unit area and their damage to leaves are usually held to be higher in monospecific stands than in species-rich ecosystems (Crawley, 1983). However, according to Connell \& Lowman (1989), a monodominant stand can occur when a species has lower seed predation or superior resistance to pathogens and/or herbivores. It should have also the ability to persist in greater numbers in the understorey and subsequently the canopy, by replacing one canopy element after another (Hart, 1995).

In 1992, a mass defoliation of newly emergent leaves on adult trees of the deciduous Peltogyne gracilipes Ducke (Caesalpiniaceae) was observed in Peltogyne forests (monodominant or not) on Maracá Island, and was more severe in monodominant stands (Nascimento \& Proctor, 1994). The monodominant forests are here referred to as Peltogyne-rich forest (PRF), whereas stands where Peltogyne is infrequent are called Peltogyne-poor forest (PPF), and those without this species are forest without Peltogyne (FWP). The younger $(<20 \mathrm{~cm} \mathrm{dbh})$ Peltogyne in- dividuals are evergreen and neither their young leaves, nor the mature leaves on adult trees, were attacked during the mass defoliation. The mass herbivory (which was not observed in the three subsequent years of recording) fits the hypotheses of density-dependent herbivory (Janzen, 1970; Connell, 1971) and higher herbivory rates in species-poor stands (Cravley 1983). The density-dependent herbivory hypothesis predicts heavy herbivore damage on seedlings that are near adults resulting in density-dependent mortality amongst rain forest trees maintaining species densities so low that high diversity can be reached. In this paper we test the hypothesis that adult Peltogyne, as a monodominant species in PRF, is particularly prone to herbivore damage with higher herbivory rates on adult trees than the two other common (but not dominant) tree species, Ecclinusa guianensis and Pradosia surinamensis (both Sapotaceae), but that Peltogyne seedlings do not suffer mortality by density dependent herbivory (JanzenConnell model). The work also addresses the observations of Brown \& Ewel (1987) that simultaneous comparisons of herbivory rates in speciesrich and species-poor ecosystems in the same environment are lacking.

\section{MATERIALS AND METHODS}

\section{Maracá Island}

Maracá Island is a large $(100,000$ ha) island located in the River Uraricoera, a tributary of the Amazon, at about $3^{\circ} 25^{\prime} \mathrm{N}, 61^{\circ} 40^{\prime} \mathrm{W}$ in Roraima 
State, north-east Brazil. The main features of its climate, from Thompson $e t$ al. (1992) and Nascimento (1994), are: rainfall, $c .1800 \mathrm{~mm} \mathrm{yr}^{-1}$ with a dry season from October to March; mean monthly maximum temperatures ranging from $35^{\circ} \mathrm{C}$ to $41^{\circ} \mathrm{C}$ and mean monthly minima ranging from $22{ }^{\circ} \mathrm{C}$ to $24^{\circ} \mathrm{C}$.

The forests of Maracá have been described by Thompson et al. (1992) and Nascimento et al. (1997). The PRF has an average of 26 tree $(\geq 10 \mathrm{~cm} \mathrm{dbh})$ species per 0.25 ha and a Simpson diversity Index (1/Ds, Brower \& Zar, 1977) of 9.11, PPF 32 and 13.28 and FWP 31 and 17.64. Peltogyne has the highest percentage basal area in PRF with $53 \%$ ( $\geq 10 \mathrm{~cm} \mathrm{dbh})$. For the trees greater than $30 \mathrm{~cm} \mathrm{dbh}$, however, the Peltogyne monodominance is much more pronounced, reaching up to $91 \%$ of the basal area (Nascimento et al., 1997). The average number of Peltogyne, Pradosia and Ecclinusa seedlings per $\mathrm{m}^{2}$ in each plot studied by Nascimento \& Proctor (1997) ranged from 0 to 5.7 (Peltogyne), 0 to 0.9 (Pradosia) and 0 to 0.8 (Ecclinusa) in PPF and from 6.1 to 23.3 (Peltogyne), 0.4 to 13.8 (Pradosia) and 0 to 0.3 (Ecclinusa) in PRF.

This study was carried out in 50 $\mathrm{m} \times 50 \mathrm{~m}$ plots replicated three times in each of PRF, PPF, FWP and in a medium-sized gap ( $33 \mathrm{~m}$ long and 11 $m$ wide) (Brokaw, 1985) near one of the plots in the PRF.

\section{HERBIVORY ASSESSED FROM LEAVES IN LITTERFALL}

In November 1991, all leaves of
Ecclinusa (from one plot in PRF and all plots in FWP), Peltogyne (all plots in PRF and PPF) and Pradosia (all plots in PRF and FWP) in the litterfall (collected from $0.33 \mathrm{~m}^{2}$ traps, $\mathrm{n}=11$ per plot) were visually assessed for herbivory using an eleven-point scale (percentage of lamina removed): $0,<10 \%, 11-20 \%, 21-30 \%, 31-40 \%$, $41-50 \%, 51-60 \%, 61-70 \%, 71-80 \%$, $81-90 \%$, and $91-100 \%$. The damage was assumed to have been caused by chewing insects before the leaves fell into the traps. Mean leaf herbivory for each plot was calculated by multiplying the number of leaves within each damage class by the mean of that class to provide a percentage apparent leafdamage estimate (Wint, 1983).

\section{TEMPORAL VARIATION IN HERBIVORY ON PELTOGYNE AND PRADOSIA SEEDLINGS}

This part of the study was only carried out for Peltogyne in PRF, for Pradosia in FWP, and for both these species in the gap. On 1-5 August 1991 , ten seedlings ( $\leq 50 \mathrm{~cm}$ tall) of each of Peltogyne and Pradosia were chosen at random in each of the specified study plots and the gap. On each plant, the outlines of at least three leaves were traced onto graph paper and left intact on the plant. The leaves were classified into young and mature age-categories. Young leaves (group 1) were about $14 \mathrm{~d}$ old when measurement began, while most of the mature leaves (group 2) had probably been produced in the past wet season and so were about 1 yr old. The group 1 
leaves became mature after the first census. After one month (1-5 September 1991) the plants were censused for changes in the damaged area for each traced leaf, and for leaf fall and leaf production. The young leaves which were not fully expanded when marked were redrawn at the second census to allow for their increased area. Further censuses were made every two months until July 1992. Leaf area was measured using a planimeter. The area of insect damage was determined by counting the number of squares $\left(\mathrm{mm}^{2}\right)$ visible under the damaged area.

\section{SEEDLING HERBIVORY}

On 8-9 June 1992, five seedlings ( $\leq 50 \mathrm{~cm}$ tall) of each study species were chosen randomly in each plot where they occurred. All leaves from each individual were removed and their herbivore damage assessed using the eleven-point scale described above after the leaves had been separated into two age categories: young (not fully expanded, light-green and nearest the branch apices), and mature (fully expanded, dark green and located further from the apices).

A further study was made on Peltogyne recruits tagged in March 1993 in five sub-plots $(2 \mathrm{~m} \mathrm{x} 1 \mathrm{~m})$ in each study-plot. Herbivory was estimated, on one occasion only, when the plants were about $13 \mathrm{~d}$ old and still had both cotyledons and were usually without fully expanded leaves.

Leaf herbivory values were transformed (ln (\% damaged leaf area +1$)$ to obtain a normal distribution (Coley, 1983a; Zar, 1984), and comparisons among species and forest types were made by two-way nested Anova where factor A (forest type) was considered fixed and factor B (plot) random (Zar, 1984). Differences among means were calculated using Tukey's test. A Chi-square test was applied for comparisons of the proportion of damage between young and mature leaves.

\section{RESULTS}

\section{HERBIVORY ASSESSED FROM LEAVES IN LITTERFALL}

For Peltogyne (PRF and PPF) and Pradosia (PRF and FWP) there were no significant differences in $\%$ leaf area removed by herbivores (t-tests, $\mathrm{p}>0.17$ ) within species between forests. Ecclinusa did not occur in enough plots to be tested. There was a significant difference among species in PRF (one-way Anova, F=12.6, $\mathrm{p}=$ 0.001 ) reflecting the lower herbivory on Pradosia (Tab. 1).

\section{TEMPORAL VARIATION}

The proportion of leaves damaged in the gap was significantly smaller for Peltogyne than Pradosia (Chi-square test $=4.54$, d.f. $=1, \mathrm{p}<$ $0.05)$. In the understorey of each forest type the between-species differences were not significant (Chi-square test $=1.45$, d.f. $=1, p>0.05)$. For Peltogyne the number of leaves attacked by herbivores was not different between the gap and forest (Chisquare $=1.92$, d.f. $=1, p>0.05$ ), but for Pradosia there was a difference between forest and gap (Chi-square test= 
4.64, d.f. $=1, p \leq 0.05)$.

The median herbivory rates on young and mature leaves (Table 2) of Peltogyne and Pradosia seedlings were not significantly different within species and between species (MannWhitney test, $p>0.05$ ). Coefficients of variation ranged from 1.74 to 3.23 (Table 2) indicating that the variation in herbivory between plants was high in both species, with herbivory rates positively skewed so that the modal individuals suffered less damage than the mean. All leaf damage to both species in the forest plots occurred during the wet season. However, in the gap, only $50 \%$ (Peltogyne) and 35\% (Pradosia) of the leaf damage occurred in the wet season. The damage to particular individuals was not con-

Table 1. The percentage leaf area removed by herbivores from leaves (collected as litterfall) for three species in three forest types on Maracá Island, Roraima, Brazil. - indicates that the species was not recorded from that replicate plot within the forest type. PRF, Peltogyne rich forest; PPF, Peltogyne poor forest; FWP, forest without Peltogyne.

\begin{tabular}{lccc}
\hline Forest & Peltogyne & Pradosia & Ecclinusa \\
\hline PRF & & & \\
Plot 1 & 7.7 & 6.2 & - \\
Plot 2 & 11.5 & 5.3 & - \\
Plot 3 & 15.1 & 39.7 & 12.6 \\
Mean & 11.4 & 7.1 & \\
SD & 3.0 & 1.9 & \\
& & & \\
PPF & & - & - \\
Plot 7 & 19.5 & - & - \\
Plot 8 & 17.0 & - & \\
Plot 9 & 13.4 & & \\
Mean & 16.6 & & \\
SD & 2.5 & & \\
& & & \\
FWP & & 5.0 & 11.1 \\
Plot 10 & - & 4.0 & 1.2 \\
Plot 11 & - & 6.4 & \\
Plot 12 & - & 5.1 & \\
Mean & & & \\
SD & & & \\
\hline
\end{tabular}


stant over time for both species. For each sample period a different group of individuals was more heavily attacked.

Over the 11-month period, $41 \%$ of the Peltogyne leaves and $44 \%$ of the Pradosia leaves were abscised from individuals in the gap. In the understorey, the Peltogyne and Pradosia seedlings lost $63 \%$ of the leaves and the differences between gap and understorey were significant (Chisquare tests, $p<0.01$ ). There were no significant differences in leaf loss between species in both site types (Chisquare tests, $p>0.05$ ), with both species shedding more leaves during the dry season.

Herbivory was not related to survival, since the dead plants (two for Peltogyne and three for Pradosia) had no leaf damage during the study.

\section{HERBIVORY ON SEEDLING LEAVES}

There were no intraspecific differences in leaf herbivory for seedlings between forests (Table 3 ). The high coefficients of variation in Table 3 were caused by a small number of heavily damaged individuals while the average extent of damage was low (Fig. 1). The number of Peltogyne seedlings with more than $5 \%$ leaf herbivory was lower than those found for Ecclinusa and Pradosia, and only one Peltogyne individual (in PPF) suffered more than $10 \%$ leaf herbivory (Fig. 1). The number of damaged leaves was higher in mature leaves, except for Peltogyne which had a similar propor-

Table 2. Herbivory rates (mean, coefficient of variation and median) per individual of Peltogyne and Pradosia over an 11-month period in two leaf age categories: group 1, c. $14 \mathrm{~d}$ old when first censused, and group 2,c. 1 yr old at the first census. PRF, Peltogyne rich forest; PPF, Peltogyne poor forest; FWP, forest without Peltogyne.

\begin{tabular}{lcccc}
\hline $\begin{array}{c}\text { Species and } \\
\text { location }\end{array}$ & $\begin{array}{c}\text { Mean } \\
\text { (\%/day) }\end{array}$ & CV (\%) & $\begin{array}{c}\text { Median } \\
(\% / \text { day })\end{array}$ & $\begin{array}{c}\% \text { number of } \\
\text { damaged } \\
\text { leaves }\end{array}$ \\
\hline $\begin{array}{l}\text { (a) Group 1 } \\
\text { Peltogyne }\end{array}$ & 0.0044 & 252 & 0.00 & 25 \\
Gap & 0.0005 & 300 & 0.00 & 30 \\
PRF & 0.0352 & 255 & 1.94 & 53 \\
Pradosia & 0.0205 & 204 & 0.00 & 40 \\
Gap & & & & \\
FWP & 0.0011 & 323 & 0.00 & 32 \\
(b) Group 2 & 0 & 0 & 0.00 & 32 \\
Peltogyne & & 174 & 0.00 & 76 \\
Gap & 0.0476 & 0 & 0.00 & 39 \\
PRF & 0 & & & \\
Pradosia & & & & \\
Gap & & & & \\
FWP & & & & \\
\hline
\end{tabular}


tion of damaged leaves in young and mature leaves (Tab! 4). Mature leaves were generally more damaged than young leaves (Tab. 4).

\section{HERBIVORY IN PELTOGYNE SEEDLING RECRUITS}

The herbivory on leaves of new (13 d after germination) seedlings of Peltogyne was low in both PRF and PPF. Only six of 81 (PRF) and two of
22 (PPF) newly tagged seedlings were attacked, with most seedlings having less than $5 \%$ of leaf area lost. At this time only $23 \%$ (PRF) and $27 \%$ (PPF) of the individuals had leaves fully expanded.

\section{DISCUSSION}

\section{HERBIVORY ASSESSED FROM LEAVES IN LITTERFALL}

Table 3. Mean values (with ranges) of percentage leaf area damage from seedlings of three species in three forest types on Maracá Island, Roraima, Brazil. PRF, Peltogyne rich forest; PPF, Peltogyne poor forest; FWP, forest without Peltogyne.

\begin{tabular}{lcccc}
\hline & PRF & PPF & FWP & P \\
\hline Ecclinusa & & & & \\
Mean & 9.0 & 11.9 & 9.5 & n.s. \\
range & $(0-24.3)$ & $(1.2-53)$ & $(0-38.6)$ & \\
CV & 88 & 119 & 103 & \\
P & n.s. & n.s. & n.s. & \\
& & & & \\
Peltogyne & & & & n.s. \\
Mean & 2.3 & 3.8 & - & \\
range & $(0-9)$ & $(0-7.7)$ & & \\
CV & 126 & 82 & & n.s. \\
Pradosia & & & & \\
Mean & 9.0 & 7.2 & 11.9 & $(0-35)$ \\
range & $(0-22.5)$ & $(0-33.7)$ & 95 & \\
CV & 83 & 127 & & \\
\hline
\end{tabular}

$\mathrm{CV}=$ Coefficient of variation $(\%)$.

$\mathrm{p}=$ probabilities, $n . s=$ not significant. 


\section{Peltogyne gracilipes}

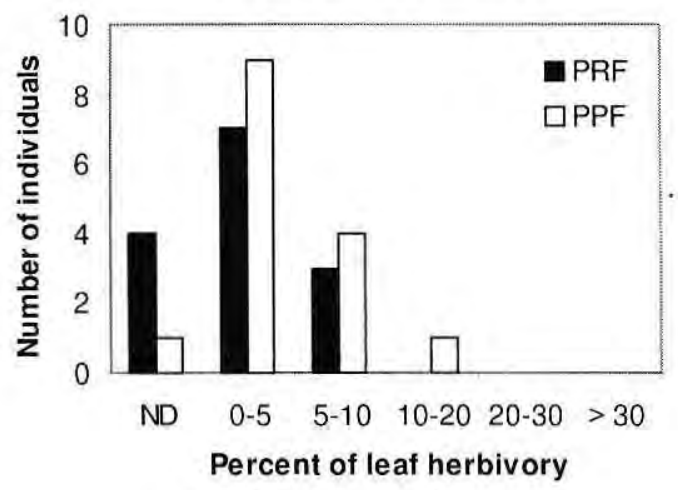

Pradosia surinamensis

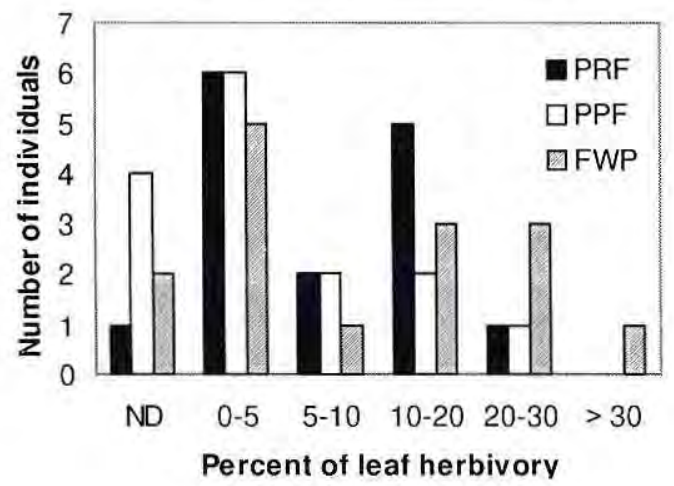

Ecclinusa guianensis

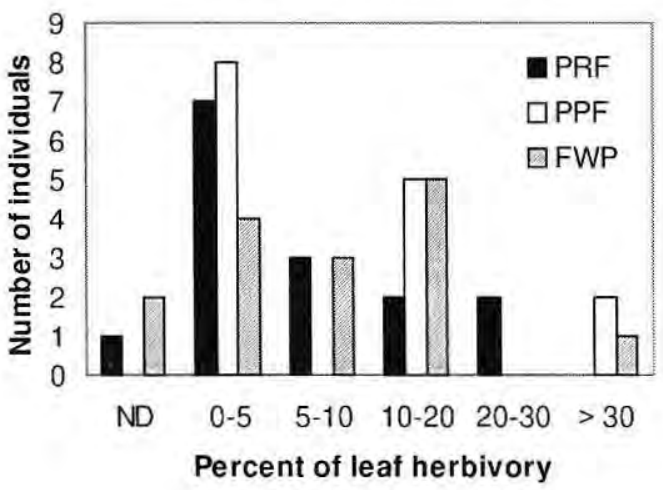

Figure 1. Intraspecific variation in leaf herbivory on seedlings ( $<50 \mathrm{~cm}$ tall) of three study species in Peltogyne rich forest (PRF); Peltogyne poor forest (PPF); forest without Peltogyne (FWP). 
Table 4. The percentage of damaged leaves and mean of percentage damaged area per individual in two leaf age categories (young, YL; and mature, ML) in three forest types on Maracá Island, Roraima, Brazil. PRF, Peltogyne rich forest; PPF, Peltogyne poor forest; FWP, forest without Peltogyne.

\begin{tabular}{|c|c|c|c|c|c|c|}
\hline & \multicolumn{3}{|c|}{$\%$ damaged leaves } & \multicolumn{3}{|c|}{$\%$ damaged área } \\
\hline & YL & ML & $p^{1}$ & $Y L$ & $M L$ & $p^{2}$ \\
\hline \multicolumn{7}{|c|}{ Ecclinusa } \\
\hline PRF & 17 & 57 & $* * *$ & 6.3 & 10.3 & * \\
\hline PRF & 16 & 53 & $\star \star \star \star$ & 0.5 & 14.2 & $\cdots$ \\
\hline FWP & 16 & 59 & $* \star * *$ & 2.4 & 11.2 & *** \\
\hline \multicolumn{7}{|c|}{ Peltogyne } \\
\hline PRF & 12 & 30 & n.s. & 0.7 & 3.3 & $\cdot$ \\
\hline PRF & 31 & 48 & n.s. & 1.5 & 4.3 & $\because$ \\
\hline \multicolumn{7}{|c|}{ Pradosia } \\
\hline PRF & 5 & 60 & $* * *$ & 3.7 & 13.8 & $\cdots$ \\
\hline PRF & 18 & 54 & $* * *$ & 3.0 & 10.2 & n.s. \\
\hline FWP & 33 & 73 & $\star \star \star$ & 3.0 & 16.3 & $* *$ \\
\hline
\end{tabular}

$1=$ Chi-square test

$2=t$-test

$\mathrm{n} . \mathrm{S}=$ not significant

$*=0,05,{ }^{* *}=0,01,{ }^{* * *}=0,001$

The range $(5.1-16 \%$, standing damage) of mean herbivory values for the three species is within the limits recorded $(5-15 \%)$ for other tropical rain forests (Landsberg \& Ohmart, 1989; Sterk et al., 1992). An overall value of $11.3 \%$ was found by Scott (1990) for a range of species in a FWP on Maracá. Although Lowman (1984) and Filip et al. (1995) remarked that herbivory may be underestimated by the discrete sampling method, comparisons with other studies using the same technique are valid.

\section{SEEDLING HERBIVORY}

Coley et al. (1985) proposed that slower growing species would be better defended and have lower herbivory rates than faster growing species. The species in this study are slow growing (Nascimento \& Proctor, 1997) and their seedling herbivory rates, especially for Peltogyne, are relatively low when compared with those of other tree species (Lowman, 1982; Coley, 
1983a,b; Lowman, 1984; Marquis, 1987; Nascimento \& Hay, 1993). However, as found by Coley (1983b), Marquis (1984) and Nascimento \& Hay (1993), variation between plants at any one sample period is high, and rates of damage to a particular individual are not constant. It is striking, however, that the results of seedling herbivory indicate lower rates of herbivory on dense Peltogyne seedlings than on much rarer Ecclinusa and Pradosia and show no density-dependent herbivory for Peltogyne, as there was no significant difference between young-plant herbivory in PRF (high density) and PPF (low density). So escape from herbivory could be a factor leading to dominance of Peltogyne.

Site differences are one of the factors that are believed to affect herbivory (Brown \& Ewel, 1987; Marquis, 1987). No statistical differences in herbivory between forest types were seen in this study, although herbivory on Pradosia was significantly higher in the gap.

The difference found by the discrete sampling method for the percentage of herbivory between young and mature leaves probably reflects damage accumulated during leaf development, since the temporal variation method showed that herbivory rates between young leaves and mature leaves were not different.

Many authors consider that the impact of leaf damage decreases with plant age or height or both (Marquis, 1984; Nascimento \& Hay, 1994, Coley
$\&$ Barone, 1996). The low herbivory found for the seedlings of Peltogyne suggests that this species might invest more in defense of younger individuals. Their leaves were not eaten during the mass adult defoliation in 1992 (Nascimento \& Proctor, 1994).

\section{CONCLUSION}

The leaf herbivory rates of trees and seedlings of the three study species were in the range for the tropical plants. There was no evidence for density-dependent herbivory. This is in contrast to earlier observation (Nascimento \& Proctor 1994) of extensive lepidopteran defoliation of newly flushed leaves on adult Peltogyne and it is suggested that Peltogyne may be dominant due to escape from herbivory in spite of sporadic severe defoliation of newlyflushed leaves on adult trees.

\section{ACKNOWLEDGMENTS}

We are grateful to Brazilian National Research Council (CNPq) and Margaret Mee Amazon Trust for financial help. We also thank $\mathrm{Mr}$ Gutemberg Moreno (IBAMA-RR) for logistic support and Robert Marquis, Sylvia Torti and Bérites Cabral for comments on the manuscript.

\section{Literature cited}

Aide, T.M. 1992. Dry season leaf production: an escape from herbivory. Biotropica, 24: 532-537

Brokaw, N. 1985. Treefalls, regrowth, and community structure in tropical forest. In: Picket, S.T.A \& White, P.S eds. The Ecol- 
ogy of Natural Disturbance and Patch Dynamics. Academic Press, New York. p. 53-69.

Brower, J.E.; Zar, J.H. 1977. Field and laboratory methods for general ecology. W.C. Brown Company Publishers, lowa.

Brown, B; Ewel, J. 1987. Herbivory and simple tropical successional ecosystems. Ecology 68:108-116.

Coley, P. 1983a. Herbivory and defensive characteristics of tree species in a lowland tropical forest. Ecological Monographs 53:209-233.

Coley, P. 1983b. Intraspecific variation in herbivory on two tropical tree species. Ecology 64:426-433.

Coley, P., Bryant, J.; Chapin, F.S. 1985. Resource availability and plant antiherbivore defense. Science 230:895-899.

Coley, P.D.; Barone, J.A. 1996. Herbivory and plants defenses in tropical forests. Ann. Rev. Ecol. Syst. 27:305-335.

Connell, J.H. 1971. On the role of natural enemies in preventing exclusion in some marine animals and in rain forest trees. In: den Boer \& Gradwell, eds. Dynamics of populations. Proceedings of the Advanced Study Institute on Dynamics of numbers in populations. Osterbeek, The Netherlands, September 7-18, 1970. Centre for Agricultural Publishing and Documentation. Wageningen. The Netherlands. p. 298-312

Connell, J.H; Lowman, M.D. 1989. Low-diversity tropical rain forests: some possible mechanisms for their existence. American Naturalist 134:88-119.

Crawley, M. 1983. Herbivory: the Dynamics of Animal-Plant Interactions. Blackwell Scientific, Oxford. England.

Ernest, K.A. 1989. Insect herbivory on a tropical understory tree: effects of leaf age and habitat. Biotropica, 21: 194-199

Filip, V.; Dirzo, R.; Mass, J.M.; Sarukan, J. 1995. Within- and among-year variation in the levels of herbivory on the foliage of trees from a Mexican tropical deciduous forest. Biotropica 27:78-86.

Hart, T.B. 1995. Seed, seedling, and subcanopy survival in monodominant and mixed forests of the Ituri Forest, Africa. Journal of Tropical Ecology 11:443-459.

Janzen, D.H. 1970. Herbivores and the number of tree species in tropical forests. American Naturalist 104:501-528.

Kusar, T.A.; Coley, P.D. 1992. Delayed greening in tropical leaves: an anti-herbivore defense? Biotropica, 24: 256-262

Landsberg, J.; Ohmart, C. 1989. Levels of insect defoliation in forests: pattern and concepts. Trends in Ecology and Evolution 4:96-100,

Lowman, M. 1982. Effects of different rates and methods of leaf area removal on rain forest seedlings of Coachwood (Ceratopetalum apetalum). Australian Journal of Botany 30:477-483.

Lowman, M. 1984. An assessment of techniques for measuring herbivory: is rainforest defoliation more intense than we thought? Biotropica 16:264-268.

Marquis, R. 1984. Leaf herbivores decrease fitness of a tropical plant. Science 226:537-539.

Marquis, R. 1987. Variacion en la herbivoria foliar y su importancia selectiva en Piper arieianum (Piperaceae). Revista de Biologia Tropical (supplement 1) 35:133149.

Nascimento, M.T. 1989. Herbivoria foliar em Vochysia divergens Pohl. Brasil Florestal 68:51-54.

Nascimento, M.T. 1994. A Monodominant Rain Forest on Maracá Island, Roraima, Brazil: Forest Structure and Dynamics. D. Phil. Thesis. University of Stirling, Stirling, Scotland.

Nascimento, M.T.; Hay, J. 1993. Intraspecific variation in herbivory on Metrodorea pubescens (Rutaceae) in two forest types in central Brazil. Revista Brasileira de Biologia 53:143-153.

Nascimento, M.T.; Hay, J. 1994. The impact of simulated folivory on juveniles of Metrodorea pubescens (Rutaceae) in a 
gallery forest near Brasilia, Federal District, Brazil. Journal of Tropical Ecology 10:611-620.

Nascimento, M.T; Proctor, J. 1994. Insect defoliation of an Amazonian Rain Forest. Journal of Tropical Ecology 10:633-636.

Nascimento, M.T.; Proctor, J. 1996. Seed attacks by beetles and leaf-cutter ants on Peltogyne gracilipes Ducke (Caesalpiniaceae) on Maracá Island, Brazilian Amazonia. Journal of Tropical Ecology 12:723-727.

Nascimento, M.T., Proctor, J,; Villela, D.M. 1997. Forest structure, floristic composition and soils of an Amazonian monodominant forest on Maracá Island, Roraima, Brazil. Edinburgh Journal of Botany 54:1-38.

Nascimento, M.T.; Proctor, J. 1997. Population dynamics of five tree species in a monodominant Peltogyne forest and two other forest types on Maracá Island, Roraima, Brazil. Forest Ecology \& Management 94:115-128.

Scott, D.A. 1990. Litter and Mineral Nutrient Studies in a Tropical Forest on Maraca Island, Roraima, Brazil. MSc thesis, University of Stirling, Scotland.

Sterck, F., van der Meer, P.; Bongers, F. 1992. Herbivory in two rain forest canopies in French Guyana. Biotropica 24:97-99.

Thompson, J., Proctor, J., Viana, V., Milliken, W., Ratter, J.A.; Scott, D.A. 1992. Ecological studies on a lowland evergreen rain forest on Maracá 1sland, Roraima, Brazil. 1. Physical environment, forest structure and leaf chemistry. Journal of Ecology 80:689-703.

Wint, G. R. W. 1983. Leaf damage in tropical rain forest canopies. In: Sutton, S.L., Whitmore, T.C. \& Chadwick, A.C.(eds. Tropical Rain Forest: Ecology and Management. Blackwell Scientific Publications, Oxford. p. 229-239.

Zar, J.H. 1984. Biostatistical Analysis, 2nd ed. Prentice Hall International, New Jersey, U.S.A. 